\title{
Use of trimethoprim to prevent overgrowth by Proteus in the cultivation of $N$. gonorrhoeae
}

\author{
A. SETH \\ Venereal Diseases Reference Laboratory (Public Health Laboratory Service), \\ The London Hospital, London, E1 2BL
}

The gonococcus often has to be isolated from sites heavily contaminated by other bacteria, especially in cultures from the female genital tract and the rectum. The introduction by Thayer and Martin $(1964,1966)$ of ristocetin or vancomycin, colistimethate sodium, and nystatin (VCN) as selective agents made it possible to suppress overgrowth by most contaminating organisms and this greatly facilitated the isolation of the gonococcus. These agents fail to affect most strains of Proteus and swarming by this organism often prevents the isolation of the gonococcus in culture.

Trimethoprim acts synergically with sulphonamides and the combination is effective against the gonococcus (Csonka and Knight, 1967). However, it seemed from the results of Darrell, Garrod, and Waterworth (1968) that strains of Proteus were more sensitive to trimethoprim alone than were gonococci; the effect of trimethoprim on the suppression of Proteus in the presence of gonococci has therefore been studied.

\section{Material and methods}

The standard medium used in these experiments was Oxoid brain heart infusion (code number CM 225), prepared according to the manufacturers instructions, which was agarized with 1.35 per cent. New Zealand agar. The molten base was cooled to $50^{\circ} \mathrm{C}$., and 10 per cent. defibrinated horse blood (Wellcome Reagents Limited) was added and the plates were poured. For isolation of gonococci, the Thayer-Martin combination of antibiotics (Vancomycin $3 \mu \mathrm{g} . / \mathrm{ml}$. , Colistin sulphomethate sodium $7.5 \mu \mathrm{g} . / \mathrm{ml}$. and Nystatin 12.5 units $/ \mathrm{ml}$.) were added before pouring the plates. Trimethoprim lactate was dissolved in sterile distilled water at a concentration of $3200 \mu \mathrm{g} . / \mathrm{ml}$. and stored at $-20^{\circ} \mathrm{C}$.

Specimens were obtained from male and female patients attending the Whitechapel Clinic on charcoaltreated swabs in Stuart's transport medium. After plating, cultures were incubated for $\mathbf{4 8}$ hours in candle jars at $36^{\circ} \mathrm{C}$. and gonococci identified by their colonial and microscopical appearance, oxidase reaction, and fermentation tests.

Received for publication December 30, 1969

\section{Results}

Comparison of the minimum inhibitory concentration of trimethoprim lactate for strains of Proteus and gonococci Trimethoprim lactate was incorporated into plates or slopes of brain heart infusion blood agar medium at concentrations from 4 to $64 \mu \mathrm{g} . / \mathrm{ml}$. The Proteus strains were isolated from the genital tract and identified as $P$. mirabilis. They were cultivated overnight in nutrient broth. This culture was inoculated into fresh broth which was incubated for 5 hours. A loopful of this was inoculated into $2 \mathrm{ml}$. fresh broth and a loopful of this broth suspension was used as the inoculum for a set of slopes. The gonococcal inoculum was a loopful of suspension of gonococci from a plate culture diluted in broth to a standardized turbidity approximately equal to a 1 in 5 dilution of the stock suspension prepared according to the U.S. Public Health Service Manual (1961). This was inoculated on to a set of plates containing the same range of trimethoprim concentrations, eight strains being tested on the set of plates. Plates and slopes were read after $48 \mathrm{hrs}$ incubation at $36^{\circ} \mathrm{C}$. the results are shown in Table I.

TABLE I Comparison of inhibition of strains of Proteus and gonococci by trimethoprim lactate

\begin{tabular}{|c|c|c|c|c|c|c|c|}
\hline \multirow[t]{2}{*}{ Species } & \multirow{2}{*}{$\begin{array}{l}\text { Number of } \\
\text { strains }\end{array}$} & \multicolumn{6}{|c|}{$\begin{array}{l}\text { Minimum inhibitory concentration } \\
\text { of trimethoprim lactate }(\mu \mathrm{g} . / \mathrm{ml} .)\end{array}$} \\
\hline & & 4 & 8 & 16 & 32 & 64 & $>64$ \\
\hline $\begin{array}{l}P . \text { mirabilis } \\
\text { N. gonorrhoeae }\end{array}$ & $\begin{array}{l}30 \\
44\end{array}$ & 15 & 11 & $\begin{array}{l}4 \\
3\end{array}$ & $\overline{9}$ & $\overline{24}$ & $\overline{8}$ \\
\hline
\end{tabular}

From this experiment a concentration of $8 \mu \mathrm{g} . / \mathrm{ml}$. trimethoprim lactate seemed suitable for the suppression of most strains of Proteus while allowing the growth of gonococci.

Recovery of gonococci from suspensions artificially contaminated with Proteus

Strains of Proteus were grown overnight in broth and diluted in 10-fold steps up to $10^{-4}$. These were mixed with an equal volume of a suspension of 
gonococci prepared as described above and two loopfuls of the mixed suspension were plated on $(a)$ basal medium +VCN antibiotics and (b) basal medium + VCN antibiotics $+8 \mu \mathrm{g} . / \mathrm{ml}$. trimethoprim lactate.

These experiments with seven strains of Proteus are summarized in Table II.

TABLE II Growth of Proteus and gonococci in mixed culture in the presence of trimethoprim lactate

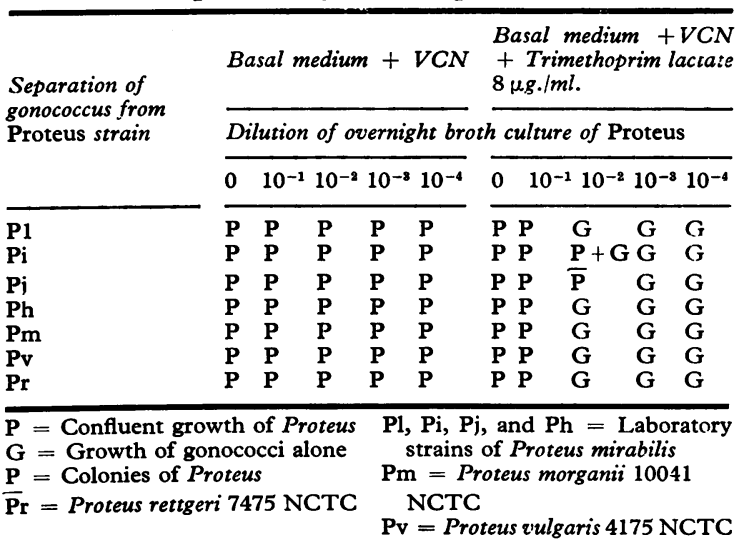

These results showed complete inhibition of a $10^{-3}$ dilution of the broth culture of Proteus. A viable count showed that this contained approximately $10^{6}$ organisms.

Effect of addition of trimethoprim on isolation of gonococci from routine clinical specimens

Specimens of exudates from 152 selected patients (82 males, 70 females) were plated on basal medium + VCN and on basal medium + VCN + trimethoprim lacate $8 \mu \mathrm{g} . / \mathrm{ml}$. The order of inoculation was rotated on alternate days. The results are shown in Table III.

TABLE III Comparison of parallel cultures for gonococci with and without trimethoprim lactate in the medium from 152 selected cases

\begin{tabular}{|c|c|c|}
\hline Result & $\begin{array}{l}\text { Basal medium } \\
+V C N\end{array}$ & $\begin{array}{l}\text { Basal medium } \\
+ \text { VCN } \\
+ \text { Trimethoprim } \\
\text { lactxte } 8 \mathrm{\mu g} . / \mathrm{ml} .\end{array}$ \\
\hline $\begin{array}{l}\text { Proteus grown } \\
\text { Gonococci grown } \\
\text { No Proteus or gonococci grown }\end{array}$ & $\begin{array}{l}58 \\
35 \\
59\end{array}$ & $\begin{array}{r}1 \\
42 \\
59\end{array}$ \\
\hline
\end{tabular}

There was some selection in the choice of specimens for study in that when previous routine cultures were found to grow Proteus, the original swabs were re-plated on the medium containing trimethoprim. This explains the high incidence of cultures for which Proteus was grown on the routine medium. The results showed that, whenever gonococci had been grown on the basal medium $+\mathrm{VCN}$, they were grown on the same medium with the addition of trimethoprim lactate. Also, the addition of trimethoprim suppressed overgrowth by Proteus in all except one instance. Seven positive cultures for gonococci were lost through swarming by Proteus on the routine medium, but they were all isolated from the new medium with trimethoprim lactate. These results indicate the potential diagnostic value of the proposed medium.

It should be stressed that, while trimethoprim is bacteriostatic and prevents swarming by Proteus, viable organisms can remain and may grow out on trimethoprim-free medium. This may hinder isolation of gonococci in pure culture for fermentation studies but despite this a presumptive diagnosis can be made from the primary plates. It was also noticed that the size of gonococcal colonies was slightly smaller on the medium containing trimethoprim than on the same medium without it; this did not prevent easy recognition of colonies.

\section{Summary}

The addition of trimethoprim lactate at a concentration of $8 \mu \mathrm{g} . / \mathrm{ml}$. to brain heart infusion blood agar plus the Thayer-Martin inhibitors was found to suppress the growth of Proteus species without interfering with the growth of $N$. gonorrhoeae. Its addition to routine media for isolation of gonococci seems worthy of trial.

My thanks are due to Dr. A. E. Wilkinson for suggesting this work and his interest in the work and to Dr. Bushby, S.R.M. (Wellcome Research Laboratories, Beckenham, Kent), for providing trimethoprim lactate; I should also like to thank Mr. G. W. Lavender for his co-operation.

\section{References}

CsonkA, G. W., and KNIGHT, G. J. (1967) Brit. f. vener. Dis., 43, 161

Darrell, J. H., Garrod, L. P., and Waterworth, P. M. (1968) F. clin. Path., 21, 202

Thayer, J. D., and Martin, J. E. (1964) Publ. Hlth Rep. (Wash.), 79, 49

- - (1966) Ibid., 81, 559

U.S. Public Health Service (1961) 'Gonococcus-Procedures for Isolation and Identification', rev. ed. (Publication 499). U.S. Government Printing Office, Washington, D.C.

Emploi de la triméthoprime pour prévenir l'envahissement par Proteus lors de la culture de $\boldsymbol{N}$. gonorrhoeae

SOMMAIRE

L'addition de lactate de triméthoprime à la concentration de $8 \mu \mathrm{g} . / \mathrm{ml}$. au milieu cerveau-coeur, gélosé au sang et supplementé des inhibiteurs de Thayer-Martin, fut trouvée capable de supprimer la pousse des espèces Proteus sans interférer avec celles de $N$. gonorrhoeae. Cette addition aux milieux de routine pour l'isolement des gonocoques semble mériter l'essai. 